\title{
MODELLING MEAN ANNUAL SEDIMENT YIELD USING A DISTRIBUTED APPROACH
}

\author{
ANTON J. J. VAN ROMPAEY, ${ }^{1,2} *$ GERT VERSTRAETEN,${ }^{1,2}$ KRISTOF VAN OOST, ${ }^{1}$ GERARD GOVERS ${ }^{1,2}$ AND \\ JEAN POESEN ${ }^{1,2}$ \\ ${ }^{1}$ Laboratory for Experimental Geomorphology, Katholieke Universiteit Leuven, Redingenstraat 16, B-3000 Leuven, Belgium \\ ${ }^{2}$ Fund for Scientific Research-Flanders
}

Received 14 August 2000; Revised 14 March 2001; Accepted 18 June 2001

\begin{abstract}
In this paper a spatially distributed model for the calculation of sediment delivery to river channels is presented (SEDEM: SEdiment DElivery Model). The model consists of two components: (1) the calculation of a spatial pattern of mean annual soil erosion rates in the catchment using a RUSLE (Revised Soil Erosion Equation) approach; and (2) the routing of the eroded sediment to the river channel network taking into account the transport capacity of each spatial unit. If the amount of routed sediment exceeds the local transport capacity, sediment deposition occurs. An existing dataset on sediment yield for 24 catchments in central Belgium was used to calibrate the transport capacity parameters of the model. A validation of the model results shows that the sediment yield for small and medium sized catchments (10-5000 ha) can be predicted with an average accuracy of 41 per cent. The predicted sediment yield values with SEDEM are significantly more accurate than the predictions using a lumped regression model. Moreover a spatially distributed approach allows simulation of the effect of different land use scenarios and soil conservation techniques. Copyright (c) 2001 John Wiley \& Sons, Ltd.
\end{abstract}

KEY WORDS: soil erosion; sediment delivery; suspended load; Belgium

\section{INTRODUCTION}

Sediment delivery to river channels is probably the most problematic off-site consequence of soil erosion. Soil erosion represents a major factor in the pollution of surface waters. The input of sediment by erosion processes into rivers, reservoirs and ponds results in high sediment deposition rates and frequent dredging operations (e.g. Verstraeten and Poesen, 1999). Moreover, in areas with intensive agricultural land use, certain nutrients and pesticides are strongly adsorbed onto soil particles (Steegen et al., 2001; Verstraeten and Poesen, 2000).

All these problems are related to the process of surface runoff in a catchment. If the surface runoff cannot sustain enough transport capacity, the sediment is deposited at intermediate locations. Although most erosion and sediment deposition processes have been studied in detail, modelling the linkage of on-site soil erosion rates within a basin to the sediment yield at the basin outlet is often problematic because of the lack of detailed input data at a river catchment scale $\left(100-10000 \mathrm{~km}^{2}\right)$.

Therefore sediment yield models are often based on an empirical lumped approach (e.g. Walling, 1983; Atkinson, 1995; Bazoffi et al., 1996; Verstraeten and Poesen, 2001). Sediment yield rates are estimated using average basin characteristics such as basin size, drainage density, mean slope, mean land cover, mean soil type, etc. A typical lumped concept is the sediment delivery ratio. The sediment delivery ratio (SDR) is defined as the ratio of sediment delivered at the catchment outlet to gross erosion within the basin. The SDR represents the resultant of various processes involved between on-site soil erosion and downstream sediment yield. Several researchers (e.g. Klaghofer et al., 1992; Bazoffi et al., 1996; Vanoni, 1975; Roehl, 1962) developed sediment delivery equations from studies of basins located in particular regions. Sediment * Correspondence to: A. Van Rompaey, Laboratory for Experimental Geomorphology, Katholieke Universiteit Leuven, Redingenstraat
16, B-3000 Leuven, Belgium. E-mail: Anton.vanrompaey@geo.kuleuven.ac.be 
delivery ratios generally decrease with increasing basin size, indexed by the area or stream length (Ferro and Minacapilli, 1995). Vanoni (1975) suggested the use of the following power function:

$$
\mathrm{SDR}=k A^{n}
$$

where $k$ and $n$ are numerical constants, and $A$ is the basin area $\left(\mathrm{km}^{2}\right)$. In general $n$ varies between $-0 \cdot 01$ and $-0 \cdot 25$. The inverse relationship between SDR and $A$ can be explained by the upland theory of Boyce (1975). According to this theory the steepest areas of a basin are the main sediment-producing zones. Since average slope decreases with increasing basin size the sediment production per unit area decreases too. Large basins also have more sediment storage sites located between sediment source areas and the basin outlet. Lumped sediment delivery equations are frequently used for engineering applications like the estimation of filling rates of retention ponds and the maintenance costs of hydroelectric power plants (USDI, 1987; Bazoffi et al., 1996).

The predictive ability of this kind of equation, however, is limited to the particular regions they have been developed from. Inherent to this lumped approach is that it is not possible to take into account the spatial structure of land use and topography within the catchment on sediment delivery. This inherently limits their applicability to practical problems such as the evaluation of different land management strategies on sediment delivery.

Ferro et al. (1998) proposed a more sophisticated lumped approach. They divided the catchment of interest in several homogeneous morphological units. The soil loss in each morphological unit was estimated using the Universal Soil Loss Equation (USLE; Wishmeier and Smith, 1978). For each unit the mean travel time of the eroded particles was estimated by means of an empirical model. Travel times were used to calculate an SDR value for each morphological unit. Eventually, the total SDR value of the catchment was derived taking into account the topological structure of the catchment. This approach is able to take some of the spatial variation of the topography into account. However, the division of the catchment into morphological units, which has a strong effect on the predictions, is more or less arbitrary. Moreover the spatial pattern of land use is not taken into account.

In principle these problems can be solved by using a distributed model, whereby the eroded sediment is explicitly routed over the landscape towards the river system, allowing for sediment deposition when the transport capacity is exceeded. The dependence of the sediment delivery processes on local factors (sediment detachment, transport capacity and topography of the drainage basin) emphasizes the need to use a spatially distributed model. However, the increasing complexity of physically based erosion/sediment deposition models such as EUROSEM (Morgan et al., 1998) or WEPP (Nearing et al., 1989) has a considerable impact on the data requirements. Often it is technically or financially impossible to gather high-precision data at the scale of a large catchment.

Pilotti and Bacchi (1997) proposed a distributed sediment delivery model that routes sediment according to a user-defined topology. Sediment deposition occurs when the topographic gradient is lower than a given threshold. The accuracy of their approach, however, is not known since the model was not validated with measured sediment yield values. For individual fields and first-order catchments soil erosion and sediment deposition models have been developed by Desmet and Govers (1995) and Van Oost et al. (2000). The predicted long- and medium-term soil redistribution patterns were validated using ${ }^{137} \mathrm{Cs}$ sampling. However, the necessary data to calibrate and validate such a model structure for large catchments are often not available.

In this paper a simple but distributed modelling structure (SEDEM: SEdiment DElivery Model) is proposed that allows the simulation of sediment delivery processes at a catchment scale (100 to $\left.10000 \mathrm{~km}^{2}\right)$. The model was applied on several catchments in central Belgium for which medium-term sediment export measurements as well as spatially distributed data on topography, land use and soils are available.

\section{MATERIALS AND METHODS}

\section{Modelling structure}

The proposed model has a structure similar to the WATEM model developed by Van Oost et al. (2000). It has three main components: (1) the assessment of a mean annual soil erosion rate for each grid cell; (2) the 
assessment of a mean annual transport capacity for each grid cell; and (3) a sediment routing algorithm that redistributes the produced sediment over the catchment taking into account the topology of the catchment and the spatial pattern of the transport capacity.

Assessment of the mean annual soil erosion rate. The erosion component consists of an adapted version of the Revised Soil Erosion Equation (RUSLE; Renard et al., 1997) The equation is:

$$
E=R K L S C P
$$

where $E$ is the mean annual soil loss $\left(\mathrm{kg} \mathrm{m}^{-2} \mathrm{a}^{-1}\right), R$ is the rainfall erosivity factor (MJ $\mathrm{mm} \mathrm{m}^{-2} \mathrm{~h}^{-1} \mathrm{a}^{-1}$ ), $K$ is the soil erodibility factor $\left(\mathrm{kg} \mathrm{h} \mathrm{MJ}^{-1} \mathrm{~mm}^{-1}\right), L$ is the slope length factor, $S$ is the slope gradient factor, $C$ is the crop management factor, and $P$ is the erosion control practice factor.

In order to adapt the RUSLE to a two-dimensional landscape, the upslope length was replaced by the unit contributing area, i.e. the upslope drainage area per unit of contour length. The latter can be calculated using a procedure proposed by Desmet and Govers (1996):

$$
L_{i, j}=\frac{\left(A_{i, j}+D^{2}\right)^{m+1}-A_{i, j}^{m+1}}{D^{m+2} x_{i, j}^{m}(22 \cdot 13)^{m}}
$$

where $L_{i, j}$ is the slope length factor for the grid cell with co-ordinates $(i, j), A_{i, j}$ is the contributing area at the inlet of a grid cell $\left(\mathrm{m}^{2}\right), D$ is the grid cell side length (m), $x_{i, j}=\sin \alpha_{i, j}+\cos \alpha_{i, j}, \alpha_{i, j}$ is aspect direction for the grid cell $(i, j)$, and $m$ is the slope length exponent.

Field observations indicate that this two-dimensional approach of the RUSLE not only accounts for interrill and rill erosion but also to some extent for ephemeral gully erosion as effects of flow convergence are explicitly accounted for (Desmet and Govers, 1997).

Assessment of the mean annual transport capacity. For each grid cell a mean annual transport capacity $T_{\mathrm{C}}\left(\mathrm{kg} \mathrm{m}^{-1}\right)$ was assessed. TC is the maximum mass of soil that can exit a grid cell per unit length of the downslope face of the square. Desmet and Govers (1995) and Van Oost et al. (2000) considered the mean annual transport capacity to be directly proportional to the potential rill (and ephemeral gully) erosion:

$$
T_{\mathrm{C}}=K_{\mathrm{TC}} E_{\mathrm{PR}}
$$

where $T_{\mathrm{C}}$ is the transport capacity $\left(\mathrm{kg} \mathrm{m}^{-1} \mathrm{a}^{-1}\right), K_{\mathrm{TC}}$ is the transport capacity coefficient (m), and $E_{\mathrm{PR}}$ is the potential for rill erosion $\left(\mathrm{kg} \mathrm{m}^{-2} \mathrm{a}^{-1}\right)$.

The transport capacity coefficient $K_{\mathrm{TC}}(\mathrm{m})$ describes the proportionality between the potential for rill erosion and the transport capacity. It can be interpreted as the theoretical upslope distance that is needed to produce enough sediment to reach the transport capacity at the grid cell, assuming a uniform slope and discharge.

The potential for rill erosion $\left(E_{\mathrm{PR}}\right)$ assessed by subtracting the potential interrill erosion $\left(E_{\mathrm{PIR}}\right)$ from the potential total erosion $\left(E_{\mathrm{PT}}\right)$ (eq. 5).

$$
E_{\mathrm{PR}}=E_{\mathrm{PT}}-E_{\mathrm{PIR}}
$$

where $E_{\mathrm{PT}}$ is potential total erosion (rill + interrill) $\left(\mathrm{kg} \mathrm{m}^{-2} \mathrm{a}^{-1}\right), E_{\mathrm{PR}}$ is potential rill erosion $\left(\mathrm{kg} \mathrm{m}^{-2} \mathrm{a}^{-1}\right)$ and $E_{\mathrm{PIR}}$ is potential interrill erosion $\left(\mathrm{kg} \mathrm{m}^{-2} \mathrm{a}^{-1}\right)$.

A potential soil erosion rate is a theoretical erosion rate $\left(\mathrm{kg} \mathrm{m}^{-2} \mathrm{a}^{-1}\right)$ assuming that the field is bare and no soil conservation measures are undertaken. The RUSLE facilitates the assessment of both actual soil erosion rates and potential soil erosion rates. In the latter case the $C$ and $P$ factors of Equation 2 are equal to one. The potential soil erosion rate $\left(E_{\mathrm{PT}}\right)$ can therefore be assessed as:

$$
E_{\mathrm{PT}}=R K L S
$$

where $E_{\mathrm{PT}}$ is the potential soil loss (rill and interrill) $\left(\mathrm{kg} \mathrm{m}^{-2} \mathrm{a}^{-1}\right), R$ is the rainfall erosivity factor (MJ $\mathrm{mm}$ $\left.\mathrm{m}^{-2} \mathrm{~h}^{-1} \mathrm{a}^{-1}\right), K$ is the soil erodibility factor $\left(\mathrm{kg} \mathrm{h} \mathrm{MJ}^{-1} \mathrm{~mm}^{-1}\right), L$ is the slope length factor and $S$ is the slope gradient factor. 
According to McCool et al. (1989), the potential for interrill erosion $\left(E_{\mathrm{PIR}}\right)$ can be estimated as:

$$
E_{\mathrm{PIR}}=a R K_{\mathrm{IR}} S_{\mathrm{IR}}
$$

where $a$ is a coefficient, $K_{\mathrm{IR}}$ is interrill soil erodibility factor $\left(\mathrm{kg} \mathrm{h} \mathrm{MJ}^{-1} \mathrm{~mm}^{-1}\right)$ and $S_{\mathrm{IR}}$ is interrill slope gradient factor.

Data are not available to estimate $K_{\mathrm{IR}}$. Therefore it was assumed that $K_{\mathrm{IR}}=K$. The slope factor for interrill erosion was calculated using the equation proposed by Govers and Poesen (1988):

$$
S_{\mathrm{IR}}=6 \cdot 86 S_{\mathrm{g}}^{0 \cdot 8}
$$

where $S_{\mathrm{g}}$ is slope gradient $\left(\mathrm{m} \mathrm{m}^{-1}\right)$.

The coefficient $a$ in Equation 7 was set at 0.6. The constant (6.86) in Equation 8 was so chosen that the interrill erosion rate equals the rill erosion rate on a 0.06 slope at a distance of $65 \mathrm{~m}$ from the divide. These parameter values agree with observations of Govers and Poesen (1988). The exponent in Equation 8 is equal to the value proposed by Foster (1982).

The combination of Equations 5, 6, 7 and 8 results in:

$$
T_{\mathrm{C}}=K_{\mathrm{TC}}\left(R K L S-a R K_{\mathrm{IR}} S_{\mathrm{IR}}\right)=K_{\mathrm{TC}} R K\left(L S-a S_{\mathrm{IR}}\right)
$$

$K_{\mathrm{TC}}$ values for the different types of land use in the catchment have to be assessed by means of calibration.

Sediment routing. Once the mean annual erosion rate and the mean annual transport capacity are known at each grid cell, a routing algorithm can be used to transfer the eroded sediment from the source to the river network. Starting from the highest grid cells in the landscape the sediment is routed downslope. For each grid cell a continuous flowpath towards the river system was determined. The flowpath network needs to be topologically consistent, i.e. flowpaths may only end at the river channel and no circular flowpaths may exist. Desmet and Govers (1995) and Van Oost et al. (2000) used multiple flow algorithms to solve this problem. However, it was found that it was difficult to construct a topologically consistent flowpath network using such algorithms for large areas. Therefore a single-flow algorithm was used. In order to make sure that no flowpaths are interrupted, the digital elevation model (DEM) was corrected with a pit-removal algorithm (Clark Labs, 1999). The construction of flowpaths has started then by determining the outflow cell for the grid cell in the upper left corner of the DEM using the steepest descent criterion. This means that the lowest of the eight neighbouring cells is selected as outflow cell. Next, the outflow cell of the former outflow cell is determined. This procedure is repeated until a stream channel, the border of the DEM or an existing flowpath is reached. Construction of flowpaths continues until an outflow cell is determined for each cell. When the flowpath reaches a river-cell all the sediment is delivered to the river. The construction of flowpaths is purely topographically determined. Since land use has not been taken into consideration flowpaths may cross several land use classes.

For each cell the amount of sediment input is added to the amount of soil erosion in that cell. If the sum of the sediment input and the local sediment production is lower than the transport capacity then all the sediment is routed further downslope. If this sum exceeds the transport capacity then sediment output from the cell is limited to the transport capacity. In the latter case, limited erosion will occur if the transport capacity exceeds the sediment input to the cell. If the transport capacity is lower than the sediment input, there will be sediment deposition.

Before the routing of sediment over the landscape can be carried out it is necessary to define the topological relations between the grid cells. The output of the model consists of a pixel map representing the amount of erosion or sediment deposition at each pixel. Furthermore the amount of sediment that reaches the river channels is calculated. The sediment yield (SY, in $\mathrm{t} \mathrm{a}^{-1}$ ) can be expressed as an absolute value. An area-specific sediment yield value (SSY, in $\mathrm{t} \mathrm{ha}^{-1} \mathrm{a}^{-1}$ ) can be calculated when the absolute sediment yield value is divided by the catchment area. 


\section{Study area}

In order to calibrate and validate the model it was applied to 21 catchments, all situated in the hilly region of central Belgium (Figure 1). The region is situated at the transition zone from the coastal plains in the north and the lowland plateaus in the south. This transition zone is strongly incised by rivers draining to the north. The silt loam and sandy silt soils under agricultural land are very sensitive to soil erosion. The overall average soil erosion rate is $c .4 .3 \mathrm{t} \mathrm{ha}^{-1} \mathrm{a}^{-1}$ in the study area (including forest and built-up area) (Van Rompaey et al., 2000). The average field size in the selected catchments is 2.3 ha. The land is especially vulnerable to erosion in spring and early summer when typical summer crops like sugar beet (Beta vulgaris L.) maize (Zea mays L.), potatoes (Solanum tuberosum L.) and chicory (Chicory intybus L.) have a low vegetation cover (Vandaele and Poesen, 1995; Verstraeten and Poesen, 1999; Steegen et al., 2000).

For all 21 catchments, ranging in size from 7 to 4873 ha, the mean annual sediment yield was estimated using three different techniques, depending on the size of the catchment area and available data: (1) measurements of erosion and deposition volumes in catchments; (2) measurement of suspended load in rivers; and (3) measurement of sediment deposition volumes in retention ponds (Table I).

The measurement of erosion and sediment deposition volumes is very labour intensive and requires regular surveys of the catchment. Four catchments in central Belgium were monitored on a regular basis (Vandaele and Poesen, 1995; Vandaele, 1997; Steegen et al., 2000). After each storm, volumes of rills and gullies and volumes of sediment deposition spots were measured on the field. By subtracting the measured sediment deposition volumes from the measured erosion volumes, sediment yield values were calculated.

The measurement of sediment deposition volumes in retention ponds facilitates the assessment of long-term sediment yield values. Verstraeten and Poesen (2001) assessed the mean annual sediment yield of 20 drainage basins in central Belgium taking into account the trap efficiency of the retention pond and the dry sediment bulk density of the measured sediment deposition. The accuracy of sediment yield estimates was assessed at 20 per cent (one standard deviation). (Verstraeten and Poesen, 2001). The sediment export values range from 55 to $3141 \mathrm{t} \mathrm{a}^{-1}$.

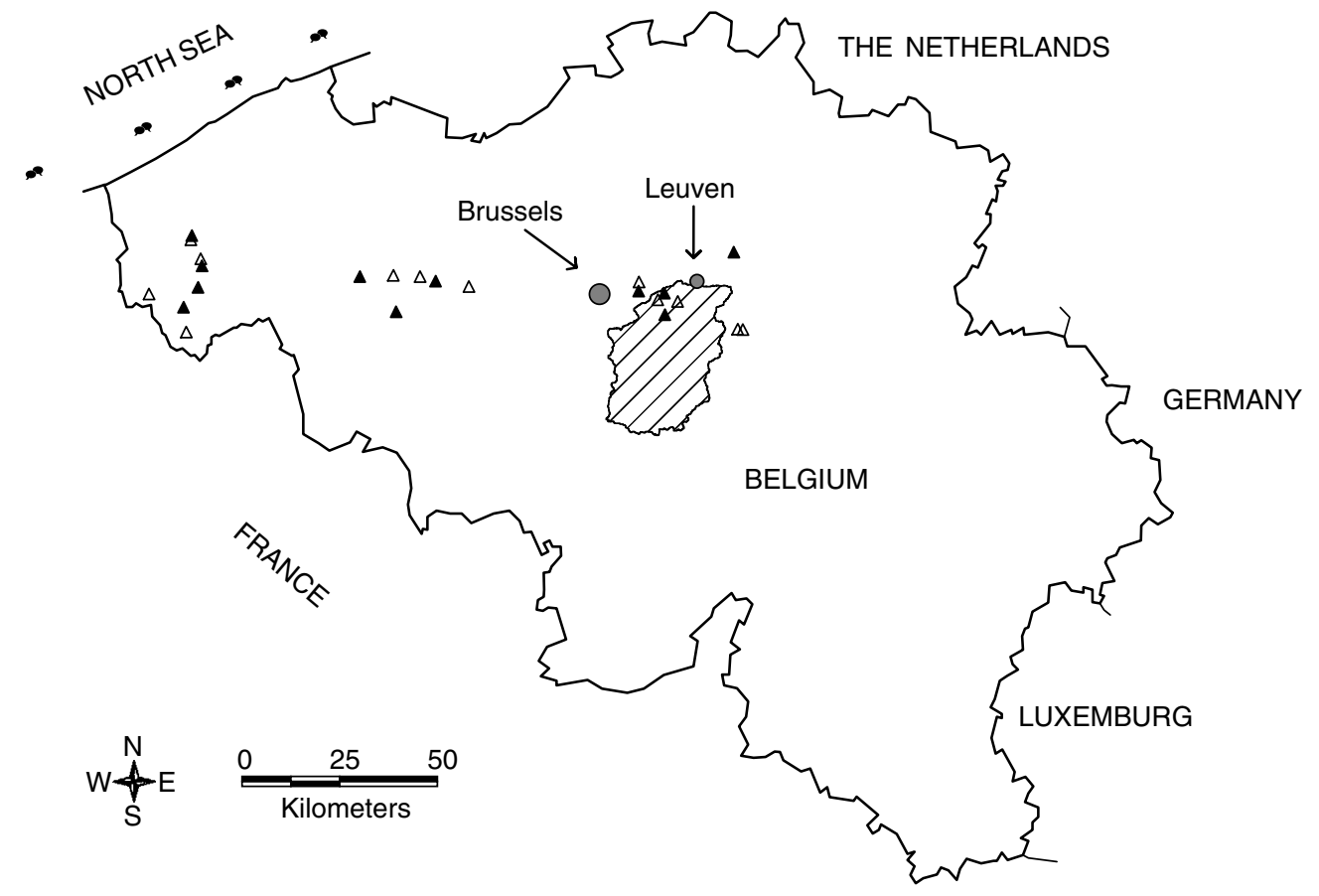

Figure 1. Situation of the Dijle catchment (hatched area). Black triangles, catchments used for validation; white triangles, catchments used for validation 
Table I. Measured and modelled sediment yield (the first 11 catchments were used for model calibration, the next 10 for model validation)

\begin{tabular}{|c|c|c|c|c|c|c|c|c|}
\hline Catchment & $\begin{array}{l}\text { Area } \\
\text { (ha) }\end{array}$ & $\begin{array}{c}\text { Obs. } \\
\text { method* }\end{array}$ & $\begin{array}{l}\text { Obs. } \\
\text { SY }\end{array}$ & $\begin{array}{l}\text { Obs. } \\
\text { SSY }\end{array}$ & $\begin{array}{c}\text { SEDEM } \\
\text { SY }\end{array}$ & $\begin{array}{c}\text { SEDEM } \\
\text { SSY }\end{array}$ & $\begin{array}{c}\text { Regress. } \\
\text { SY }\end{array}$ & $\begin{array}{c}\text { Regress. } \\
\text { SSY }\end{array}$ \\
\hline Sterrebeek & 7 & A & 55 & 7.9 & & & & \\
\hline Hammeveld 2 & 25 & $\mathrm{~A} / \mathrm{B}$ & 277 & $11 \cdot 1$ & & & & \\
\hline Ganspoel & 117 & $\mathrm{C}$ & 562 & 4.8 & & & & \\
\hline Zwedebeek & 176 & $\mathrm{C}$ & 282 & 1.6 & & & & \\
\hline Holsbeek & 226 & A & 1053 & $4 \cdot 7$ & & & & \\
\hline Nederaalbeek & 269 & $\mathrm{C}$ & 444 & 1.7 & & & & \\
\hline Bellewaerde-beek & 1050 & $\mathrm{~A}$ & 2384 & $2 \cdot 3$ & & & & \\
\hline Kemmelbeek & 1138 & A & 3005 & $2 \cdot 6$ & & & & \\
\hline Zouwbeek & 1362 & A & 1988 & 1.5 & & & & \\
\hline Steenbeek & 1915 & A & 3141 & 1.6 & & & & \\
\hline Stjansbeek & 4873 & A & 1852 & 0.4 & & & & \\
\hline Nerm & 20 & $\mathrm{~A}$ & 411 & $20 \cdot 6$ & 319 & $15 \cdot 9$ & 259 & $7 \cdot 1$ \\
\hline Hammeveld1 & 29 & $\mathrm{~B}$ & 171 & $5 \cdot 9$ & 164 & $5 \cdot 6$ & 257 & $9 \cdot 3$ \\
\hline Wolvengracht & 148 & A & 473 & $3 \cdot 2$ & 355 & $2 \cdot 4$ & 1046 & $4 \cdot 2$ \\
\hline Nossegem & 206 & A & 723 & 3.5 & 121 & $0 \cdot 6$ & 493 & $3 \cdot 2$ \\
\hline Kinderveld & 250 & $\mathrm{~B} / \mathrm{C}$ & 945 & $3 \cdot 8$ & 1004 & $4 \cdot 0$ & 977 & $2 \cdot 1$ \\
\hline Ronebeek & 783 & A & 2420 & $3 \cdot 1$ & 1242 & 1.6 & 1397 & $3 \cdot 1$ \\
\hline Munkbosbeek & 1102 & A & 1289 & $1 \cdot 2$ & 1129 & $1 \cdot 0$ & 1506 & $0 \cdot 9$ \\
\hline Tererpenbeek & 1172 & $\mathrm{C}$ & 785 & 0.7 & 1113 & $0 \cdot 9$ & 1315 & $1 \cdot 0$ \\
\hline Rooigembeek & 1394 & $\mathrm{~A}$ & 3123 & $2 \cdot 2$ & 2745 & $2 \cdot 0$ & 1813 & $1 \cdot 1$ \\
\hline Broenbeek & 2423 & $\mathrm{~A}$ & 1381 & $0 \cdot 6$ & 841 & $0 \cdot 3$ & 1927 & $1 \cdot 3$ \\
\hline
\end{tabular}

A detailed description of the catchments can be found in Verstraeten and Poesen (2001). SY, sediment yield (t ha ${ }^{-1}$ ); SSY, area-specific sediment yield $\left(\mathrm{t} \mathrm{ha} \mathrm{h}^{-1} \mathrm{a}^{-1}\right)$.

* A, measurement of sediment deposition in retention ponds; B, measurement of erosion and sediment deposition volumes in catchments; $\mathrm{C}$, suspended load measurements.

\section{Input data}

Gulinck et al. (1996) constructed a land use map for Flanders with a $20 \mathrm{~m}$ resolution using classified LANDSAT images. For this study, the various land use classes identified on this map were reclassified into five different land use classes: built-up area, forest, pasture and orchards, arable land and water bodies. The stream network, however, was not completely captured. Therefore, the land use map was updated via an overlay with the digitized stream network made available from the Department of Environment and Infrastructure of the Flemish Administration. Soil erosion was assumed to occur only on arable land. Bollinne (1982) calculated an average $C$ value of 0.36 for a crop rotation of winter barley, winter wheat and sugar beet; this value was used in this study. In the study area, farmers do not implement any specific soil conservation techniques like contour ploughing or terrace cropping. Therefore the RUSLE $P$ value was set equal to 1 .

Digital elevation data for the study area were made available from the Belgian National Geographic Institute (NGI). The original dataset consists of a regular grid sampled every $1^{\prime \prime}$ in latitude and every $2^{\prime \prime}$ in longitude from scanned topographic maps at a scale of 1:50000. Interpolation and filtering with a low-pass filter resulted in a raster DEM representing the surface as a continuously varying surface with a resolution of $20 \mathrm{~m}$. The accuracy of this DEM was evaluated with more accurate DEMs (derived from 1:10000 topographic maps) for eight test areas. The overall root mean square error (RMSE) of the altimetric differences between the two DEMs is $3.1 \mathrm{~m}$. The correspondence is better in flat valleys and less accurate on the incised plateau. Slope gradient was calculated from this DEM using the algorithm of Zevenbergen and Thorne (1987).

A vector layer with the field boundaries of all parcels used for agriculture was made available from the GIS support centre of the Flemish administration. This file was rasterized using a resolution of $20 \mathrm{~m}$. $L$ factors for each grid cell could be calculated then from the rasterized parcel file and the DEM, using the algorithm proposed by Desmet and Govers (1996) and assuming that each parcel is a hydrologically isolated entity. 
The RUSLE $K$ was derived from the digitized soil map of Flanders. This soil map provides textural information based on the Belgian classification system (Verheye and Ameryckx, 1988). For each textural class, an average geometric mean particle size was calculated. Using the equation of Declercq and Poesen (1991), the $K$ value can then be estimated:

$$
K=3 \cdot 5+38 \cdot 8 \mathrm{e}^{-0.5\left(\frac{\log D_{\mathrm{g}}+1.519}{0.7584}\right)^{2}}
$$

where $D_{\mathrm{g}}$ is the geometric mean particle $(\mathrm{mm})$ and $K$ is the RUSLE $K$ value $\left(\mathrm{kg} \mathrm{h} \mathrm{MJ}^{-1} \mathrm{~mm}^{-1}\right)$.

The rainfall erosivity factor $(R)$ was calculated using the formula proposed by Renard et al. (1997):

$$
R=\frac{\sum_{i=1}^{j}\left(E I_{30}\right)_{i}}{N}
$$

where $E I$ is the product of the total storm energy $\left(E\right.$, in MJ) and the maximum 30 min intensity $\left(I_{30}\right.$, in $\left.\mathrm{mm} \mathrm{h}^{-1}\right),\left(E I_{30}\right)_{i}$ is $E I_{30}$ for storm $I, j$ is the number of storms in an $N$ year period and $N$ is the number of observation years.

Bollinne et al. (1979) produced an iso-erodent map for Belgium using the USLE methodology. From this map an average value of $650\left(\mathrm{MJ} \mathrm{mm} \mathrm{h}^{-1}\right)$ was derived for the Dijle catchment.

\section{MODEL CALIBRATION AND VALIDATION}

The erosion component of the model is based on the RUSLE. Calibration of the RUSLE parameters for the Belgian Loess Belt had already been carried out by Bollinne (1982), Van Rompaey et al. (2000) and Van Oost $e t$ al. (2000). Therefore, the RUSLE parameters in our model were taken from these studies. Only the transport capacity coefficients for arable land $\left(K_{\mathrm{TC}-\mathrm{A}}\right)$ and for non-eroding surfaces $\left(K_{\mathrm{TC}-\mathrm{NE}}\right)$ were calibrated. The use of a limited number of parameters for calibration implies that optimal values can be unequivocally determined.

The calibration procedure was carried out as follows. The dataset with 24 sediment yield observations was sorted according to the size of the catchment. Next, the sorted dataset was split into two parts according to the ranking number: the records with an even ranking number were used for calibration, the records with an uneven ranking number were used for validation.

For each catchment of the calibration dataset the model was run with for $K_{\mathrm{TC}-\mathrm{A}}$ parameter values ranging from 0 to 150 and for $K_{\mathrm{TC}-\mathrm{NE}}$ parameter values ranging from 0 to 60 . For each combination of $K_{\mathrm{TC}-\mathrm{A}}$ and $K_{\mathrm{TC} \_ \text {NE }}$ a sediment yield value was calculated for the 12 catchments. This allowed a comparison of the measured and predicted values for each parameter combination. The model efficiency coefficient (ME) as proposed by Nash and Sutcliffe (1970) was used as a measure of likelihood:

$$
\mathrm{ME}=1-\frac{\sum\left(Y_{\mathrm{obs}}-Y_{\mathrm{pred}}\right)^{2}}{\sum\left(Y_{\mathrm{obs}}-Y_{\text {mean }}\right)^{2}}
$$

where ME is the model efficiency, $Y_{\text {obs }}$ is the observed value, $Y_{\text {pred }}$ is the predicted value, $Y_{\text {mean }}$ is the mean observed value. Values for ME range from $-\infty$ to 1 . The closer ME approximates 1 , the better the model will predict individual values.

The results of these simulations are plotted in Figures 2 and 3. The results show an optimal value for $K_{\mathrm{TC} \_\mathrm{A}}$ at $75 \mathrm{~m}$ and an optimal value for $K_{\mathrm{TC} \_\mathrm{NE}}$ at $42 \mathrm{~m}$. The calibration curve of the $K_{\mathrm{TC} \_\mathrm{NE}}$ has a very flat top from which it may be concluded that the model when applied on rural areas with mainly arable land, is not very sensitive to this parameter. With the optimal parameter values a model efficiency coefficient of 0.77 is obtained. 


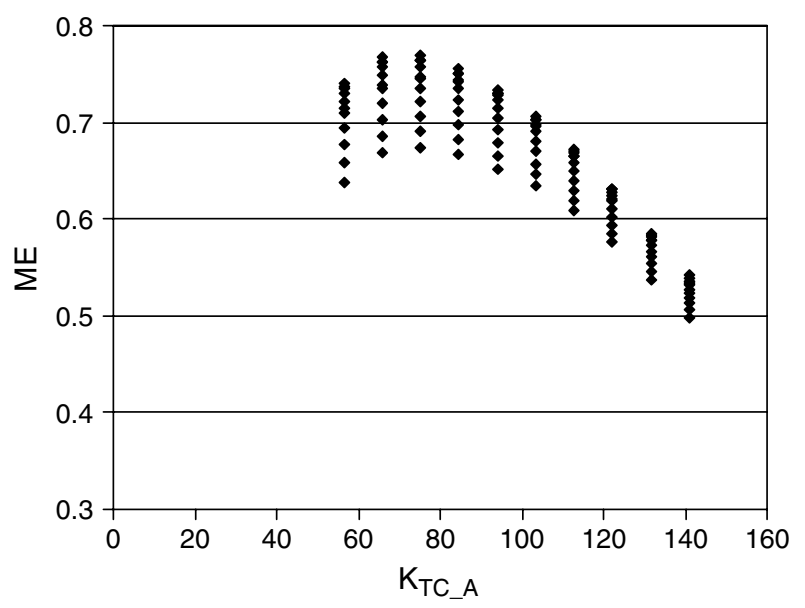

Figure 2. Calibration of the transport capacity coefficient for arable land $\left(K_{\mathrm{TC}_{-} \mathrm{A}}\right.$ in $\left.\mathrm{m}\right)$ (ME, model efficiency)

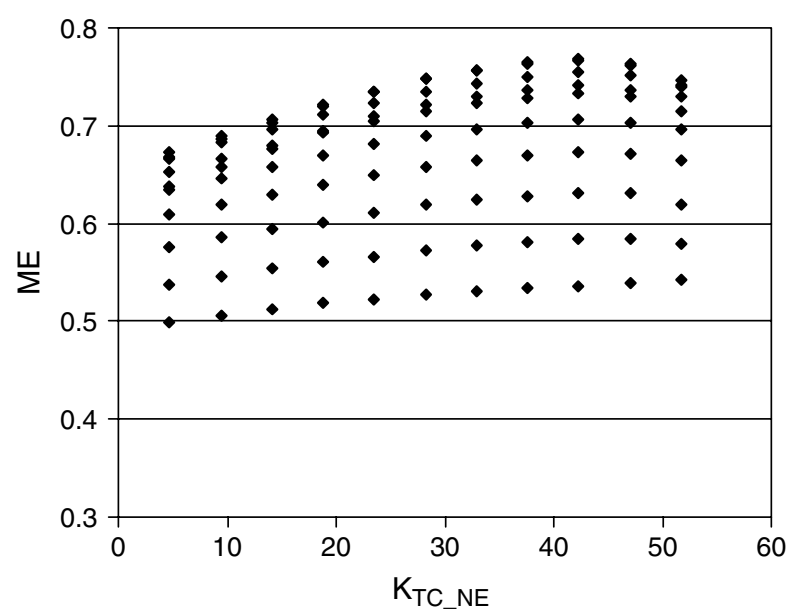

Figure 3. Calibration of the transport capacity coefficient for non-eroding surfaces ( $K_{\mathrm{TC} \_} \mathrm{NE}$ in $\left.\mathrm{m}\right)$ (ME, model efficiency)

Next the model was run for the catchments of the validation dataset. Modelled versus observed values are plotted in Figure 4.

The model accuracy was estimated using the relative root mean square error (RRMSE) as an error-measure:

$$
\operatorname{RRMSE}=\frac{\sqrt{\frac{1}{n} \sum_{i=1}^{n}\left(O_{i}-M_{i}\right)^{2}}}{\frac{1}{n} \sum_{i=1}^{n} O_{i}}
$$

where $O_{i}$ is observed sediment yield $\left(\mathrm{t} \mathrm{a}^{-1}\right), P_{i}$ is modelled sediment yield $\left(\mathrm{t} \mathrm{a}^{-1}\right)$ and $n$ is the number of catchments.

Using Equation 13 resulted in a RRMSE of 41 per cent. The proposed equation, however, does not take into account the inaccuracy of the measured sediment yield value. Verstraeten and Poesen (2001) suggested 

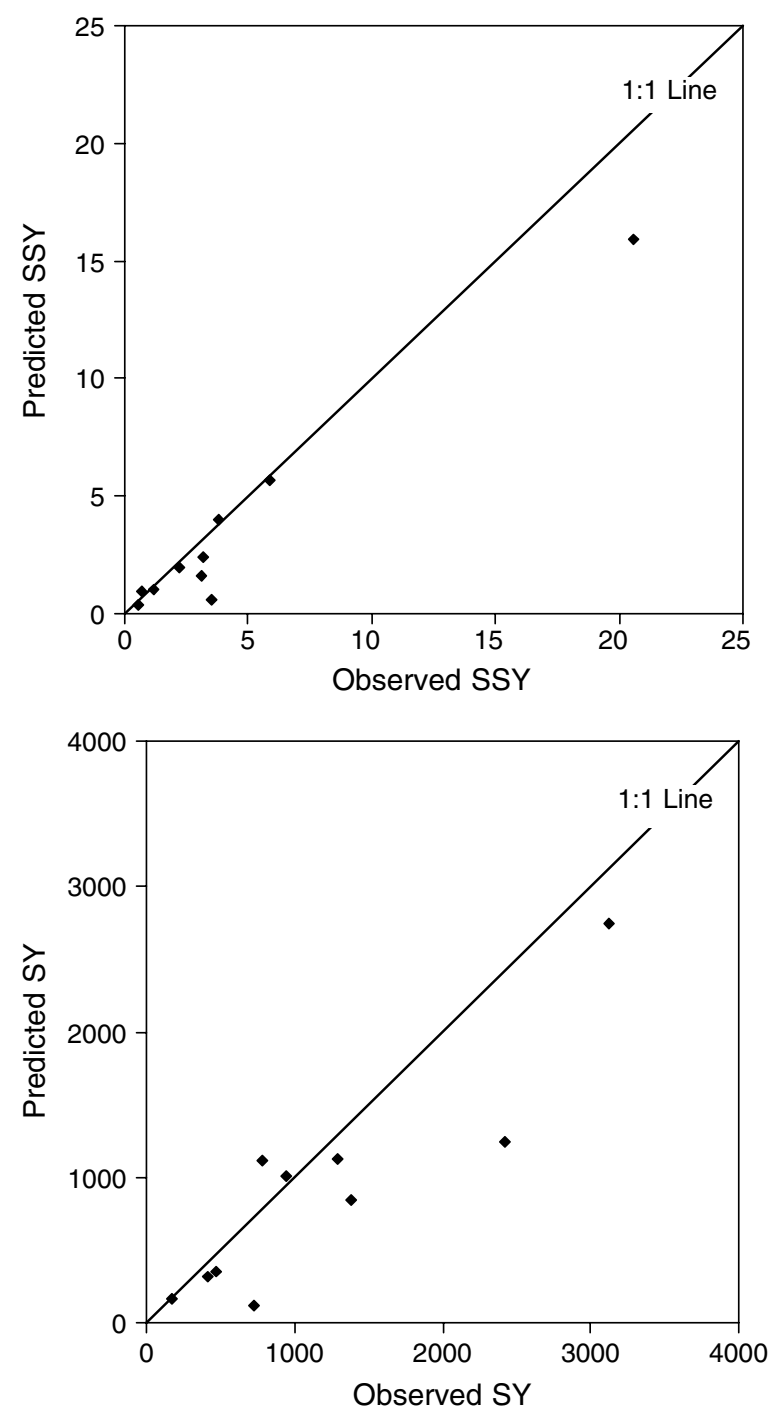

Figure 4. Observed versus modelled sediment yield ( $\mathrm{SY}$, in $\mathrm{t} \mathrm{a}^{-1}$ ) and area-specific sediment yield (SSY, in $\mathrm{tha}^{-1} \mathrm{a}^{-1}$ ) using SEDEM

that the inaccuracy involved in the calculation of sediment yield via the measurement of suspended sediment and/or the sediment deposition volume in retention ponds is about 20 per cent (relative standard error: $\sigma / v$ ).

Neglecting the error on the measured sediment export values results in an overestimation of the real error on the predicted values. The real error on the model predictions can be calculated from:

$$
\text { RRMSE }=\frac{\sqrt{\frac{1}{n} \sum_{i=1}^{n}\left(T_{i}-M_{i}\right)^{2}}}{\frac{1}{n} \sum_{i=1}^{n} T_{i}}
$$

where $T_{i}$ is the 'true' (but unknown) sediment yield $\left(\mathrm{t} \mathrm{a}^{-1}\right), P_{i}$ is predicted sediment yield $\left(\mathrm{t} \mathrm{a}^{-1}\right)$ and $n$ is the number of catchments. Equation 14, however, cannot be applied since the 'true' sediment yield values 
are not known. Li (1991) proposed a correction formula that takes into account the errors on the validation dataset. If $O T=$ observed - true $O M=$ observed - modelled $M T=$ modelled - true, then:

$$
\operatorname{VAR}(O M)=\operatorname{VAR}(O T)+\operatorname{VAR}(M T)-2 \operatorname{COV}(O T, M T)
$$

where VAR is variance, COV is covariance.

It is realistic to assume that the errors on the model predictions and the errors on the field measurements are not correlated. Therefore:

$$
2 \operatorname{COV}(O T, M T)=0
$$

or, combining Equations 15 and 16:

$$
\operatorname{VAR}(M T)=\operatorname{VAR}(O M)-\operatorname{VAR}(O T)
$$

or in this case:

$$
\operatorname{VAR}(M T)=0.41^{2}-0 \cdot 20^{2}=0 \cdot 36^{2}
$$

This means that the 'true' RRMSE of the SEDEM predictions is not 41 per cent but 36 per cent. Taking into account the corrected RRMSE it may be concluded that 66 per cent of the model predictions have an error of less than 36 per cent $(1 \sigma)$; 95 per cent of the model predictions have an error of less than 72 per cent $(2 \sigma)$. The corrected RRMSE for the area-specific sediment yield is also 36 per cent.

\section{MODEL APPLICATION}

For application at a larger spatial scale the Dijle catchment, south of Leuven, was selected (Figure 1). The basin size is about 82000 ha. The main topography is a plateau in which the Dijle and tributary rivers are incised. Height values in the area vary from $18 \mathrm{~m}$ above sea level in the north to $112 \mathrm{~m}$ in the south. The soils within the catchment are mainly loess-derived luvisols but in some places sandy outcrops exist. The land use in the catchment is mainly arable land (58 per cent) with some forest (13 per cent) and some pasture (5 per cent), mainly on valley floors. Built-up area and infrastructure occupies 24 per cent of the land.

Using the RUSLE the average erosion rate in the catchment, including the land under pasture and forest, was assessed at $4.4 \mathrm{t} \mathrm{ha}^{-1} \mathrm{a}^{-1}$. Transport capacities were calculated using the calibrated parameter values for $K_{\mathrm{TC} \_ \text {A }}(75 \mathrm{~m})$ and $K_{\mathrm{TC} \_\mathrm{NE}}(42 \mathrm{~m})$. Routing the sediment through the catchment resulted in a map with net erosion and sediment deposition rates. In most areas of the catchment net erosion occurs. For each river grid cell the amount of sediment input (SI) $\left(\mathrm{t} \mathrm{a}^{-1}\right)$ was calculated as well as the amount of upstream erosion (UE) $\left(\mathrm{t} \mathrm{a}^{-1}\right)$. Next a distributed pattern of SDR values was calculated from the equation:

$$
\mathrm{SDR}_{i}=\frac{\mathrm{SI}_{i}}{\mathrm{UE}_{i}}
$$

These SDR values were plotted against the upstream catchment area (ha) of each cell (Figure 5). The SDR values were put into area classes according to their upslope area. Figure 5 is similar to other SDR/upstream area plots but in this case all the dots belong to one catchment of which the SDR value is gradually followed downstream. The variation in SDR is very high for pixels at the channel heads (low upstream area) and gradually decreases downstream.

The predicted SDR value at the outlet of the catchment is $c .18$ per cent. This means that the model predicts a mean annual sediment export of $65700 \mathrm{t} \mathrm{a}^{-1}$ or $0.8 \mathrm{t} \mathrm{ha}^{-1} \mathrm{a}^{-1}$. Since the percentage of bedload in the Dijle is negligible, long-term suspended load data could give a good estimate of the annual sediment export. However, suspended load measurements in the Dijle are available only for short time periods. Gilles and Lorent (1966) measured the suspended load during a one-year period (1959-1960) taking one sample every two days and assessed the mean annual sediment yield at $0 \cdot 3 \mathrm{t} \mathrm{ha}^{-1}$. However, the year during which the suspended load 


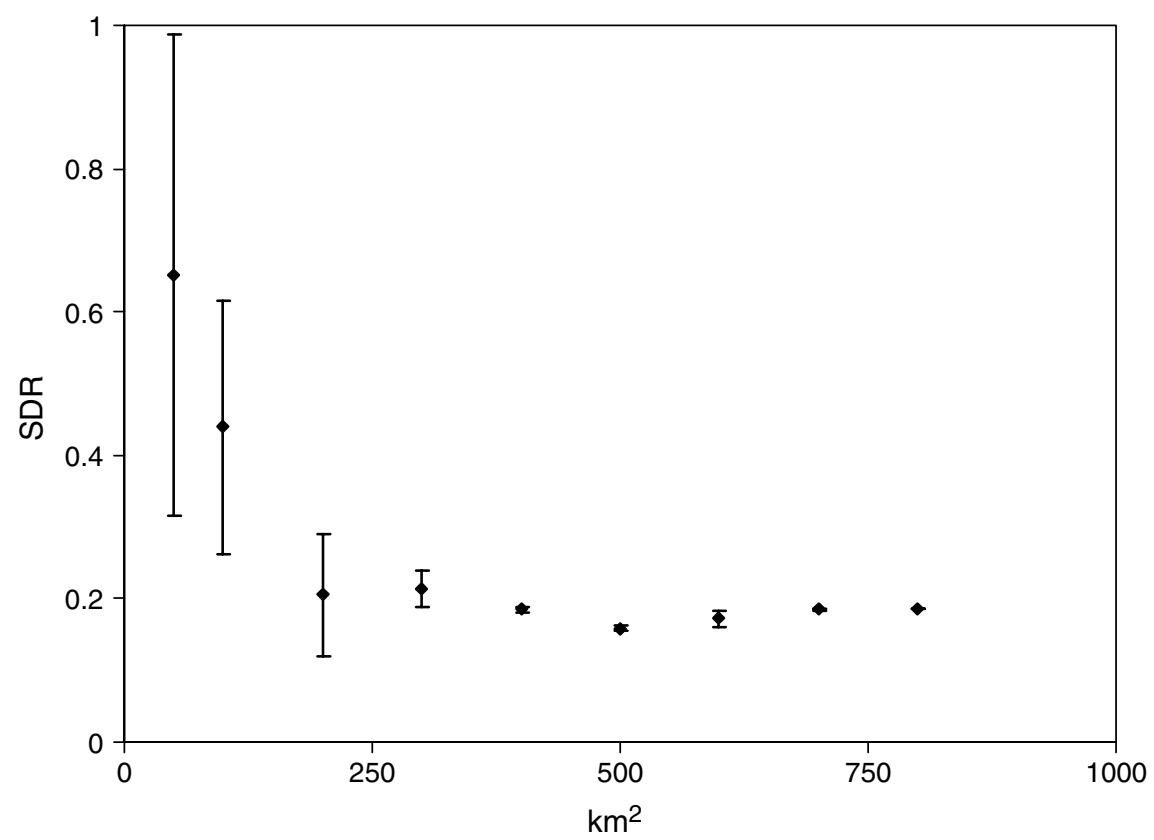

Figure 5. Sediment delivery ratios (SDR) versus upslope area for the river channels in the Dijle catchment. Pixels were divided in classes according to their upslope area. The graph shows the average SDR value and the standard deviation of each class

measurements were taken was rather dry. The mean annual precipitation in 1959 was only $594 \mathrm{~mm}$ whilst the long-term average annual precipitation is about $835 \mathrm{~mm}$. Huybrechts et al. (1989) did similar suspended load measurements in 1985 and 1986 and assessed the mean annual sediment export at $0.7 \mathrm{t} \mathrm{ha}^{-1}$. Huybrechts et al. took only one sample every month, so that their values are almost certainly underestimated. The most recent suspended load measurements were done by Steegen (personal communication) taking two samples a day with an automatic ISCO sediment sampler. After 14 months of measurement during a very wet period the mean annual sediment yield was assessed at $2 \cdot 1 \mathrm{t} \mathrm{ha}^{-1} \mathrm{a}^{-1}$ Thus, all reported values are in the same range as the prediction of our model. However, for a real validation of the model results, suspended load measurements over a longer time period are necessary. Data for a validation of the distributed pattern of erosion and sedimentation values within the Dijle catchment are not available. Nevertheless, this simulation indicates that the modelling approach developed here may also be used for larger river catchments. It should be kept in mind, though, that the proposed model only allows prediction of sediment production and delivery from water erosion on hillslopes. In larger river systems, fluvial processes like floodplain sediment deposition and river bed and bank erosion may affect or even dominate the sediment balance. The model structure presented here may still be used then to predict the sediment input into the river system by water erosion, but as a result data on river sediment loads can no longer be used for model calibration or validation.

\section{DISCUSSION}

The distributed sediment delivery model as described above was run at a resolution of $20 \mathrm{~m}$. This means that all input data, such as soil, elevation and land use data, have to be available at this resolution. Many researchers point out that a lot of topography-based models are scale dependent (e.g. Gao, 1998; Brasington and Richards, 1998, Zhang et al., 1999). Scale-dependent models will give different results when they are run at a range of grid sizes. This effect can be modulated by recalibration of the model parameters. This means that the optimal parameter values are dependent on the resolution of the application.

In order to evaluate the effect of resolution on the model output, the model was run for a range of different grid sizes without changing the calibrated parameters $K_{\mathrm{TC} \_\mathrm{A}}$ and $K_{\mathrm{TC} \_\mathrm{NE}}$. A comparison of predicted sediment 
Table II. Predicted sediment yield for the Dijle catchment using SEDEM at different grid sizes

\begin{tabular}{cc}
\hline $\begin{array}{c}\text { Grid size } \\
(\mathrm{m})\end{array}$ & $\begin{array}{c}\text { Predicted SY } \\
\left.(\mathrm{t} \mathrm{a})^{-1}\right)\end{array}$ \\
\hline 20 & 65700 \\
40 & 50200 \\
100 & 39300 \\
200 & 18600 \\
\hline
\end{tabular}

export values for the Dijle catchment shows that the results are strongly sensitive to the grid size (Table II). This can be explained by the fact that an aggregated cell should transport the same amount of sediment as the sum of the original cells. If the potential for interrill erosion in the aggregated cell has the same value, the transport capacity coefficient must be higher to result in the same transport capacity. Because of the scale dependency of the model the transport capacity coefficients must be recalibrated when running at a coarser grid size.

The optimal transport capacity coefficient for arable land $\left(K_{\mathrm{TC}_{-} \mathrm{A}}\right)$ was assessed at $75 \mathrm{~m}$ for model applications at a resolution of $20 \mathrm{~m}$. At first sight, this value corresponds relatively well with the optimal value of $69 \mathrm{~m}$ proposed by Van Oost et al. (2000). In that study an erosion and sediment deposition model for application at a scale of individual fields is proposed. The model was run at a resolution of $1 \mathrm{~m}$ and calibrated using ${ }^{137} \mathrm{Cs}$ data. Similarity between both $K_{\mathrm{TC}}$ values does not mean that the parameter values in the model are transferable from one scale to another. On the one hand the $K_{\mathrm{TC}}$ value proposed in this study can be expected to be higher because of the coarse resolution at which the model is run. Van Oost et al. (2000), however, considered sediment transport only within one field, whereas in this study sediment is routed over several fields including field boundaries that may trap sediment. This 'lumped' $K_{\mathrm{TC}}$ value may be expected to be lower than a $K_{\mathrm{TC}}$ value for pure arable land. A compensation of both factors results in similar $K_{\mathrm{TC}}$ values.

Compared with lumped regression models a distributed sediment delivery model is very data-demanding. The question may be raised whether much benefit is to be gained from a distributed model for which a lot of input data have to be gathered. Therefore the model performance was compared with the performance of a lumped regression model.

Verstraeten and Poesen (2001) developed such a sediment export model for the same study area. Sediment export values are predicted using morphological catchment parameters. This kind of empirical modelling focuses on a minimization of the unexplained variance by optimization of empirical parameters. In order to compare the model efficiency of this approach with the proposed distributed modelling structure, a multiple regression was carried out using only 12 catchments. Regression analysis resulted in the following equation for total sediment yield:

$$
S Y=0 \cdot 15 D+16 \cdot 99 H D-454 H I \quad\left(R^{2}=0.73\right)
$$

And for the area-specific sediment yield:

$$
\log (S S Y)=3.21-0.62 \log (A)-\log (H I)+0.04 \log (D L) \quad\left(R^{2}=0.75\right)
$$

where $S S Y$ is area-specific sediment export $\left(\mathrm{t} \mathrm{ha}^{-1} \mathrm{a}^{-1}\right), A$ is area (ha), $H I$ is hypsometric integral, $D L$ is drainage length (m) and $R^{2}$ is correlation coefficient of the regression.

Next the optimized regression Equations (20 and 21) were used to predict the sediment export in the other 12 catchments (Table I). A validation of these results, including the correction for imperfect validation measurements (Equation 17), shows that the RRMSE of the predicted total sediment export $\left(\mathrm{t} \mathrm{a}^{-1}\right)$ using the 

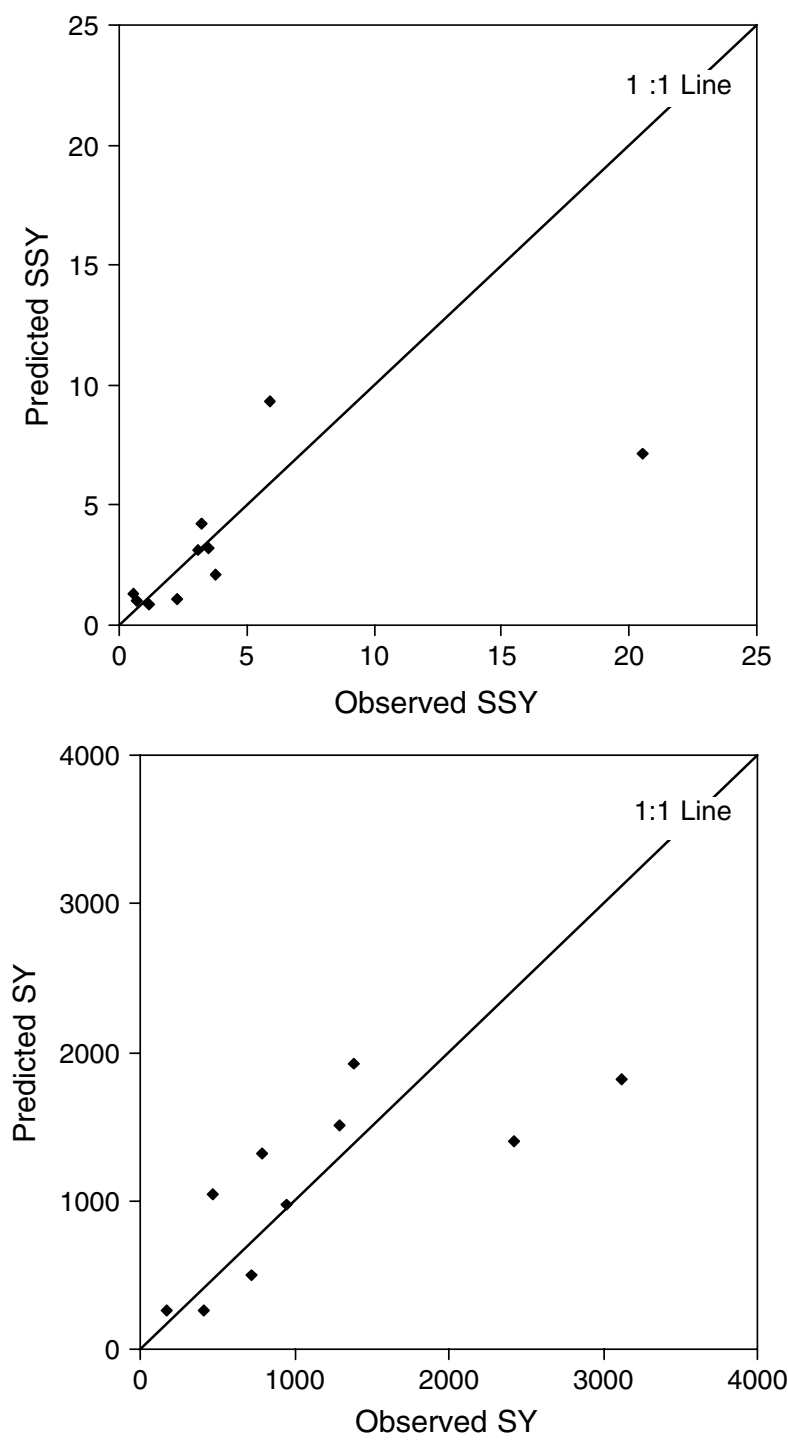

Figure 6. Observed versus modelled sediment yield (SY, in $\mathrm{t} \mathrm{a}^{-1}$ ) and area-specific sediment yield (SSY, in $\mathrm{t} \mathrm{ha}^{-1} \mathrm{a}^{-1}$ ) using a lumped regression model

lumped regression model of Verstraeten and Poesen (in press) is 49 per cent. This is 13 per cent higher than the RRMSE value using the distributed approach proposed in this study (Figures 4 and 6).

The difference in model performance is even bigger when we look at the prediction of the relative sediment export $\left(\mathrm{t} \mathrm{ha}^{-1} \mathrm{a}^{-1}\right)$. The relative sediment export values are predicted with a standard deviation of 98 per cent with the lumped regression model whereas the standard deviation using the distributed model is only 36 per cent (Figures 4 and 6). In general the lumped regression model fails to predict the sediment yield of small catchments that usually have a huge area-specific sediment export. This is because this group of catchments is very heterogeneous concerning the topography and the percentage of arable land: some of them may be completely under arable land while others may have large parts under forest or pasture. For larger catchments in the validation dataset these land use percentages are more constant.

The proposed distributed model not only performs better than the lumped regression model but also provides much more information. It is possible to identify the critical areas delivering most of the sediment to the 

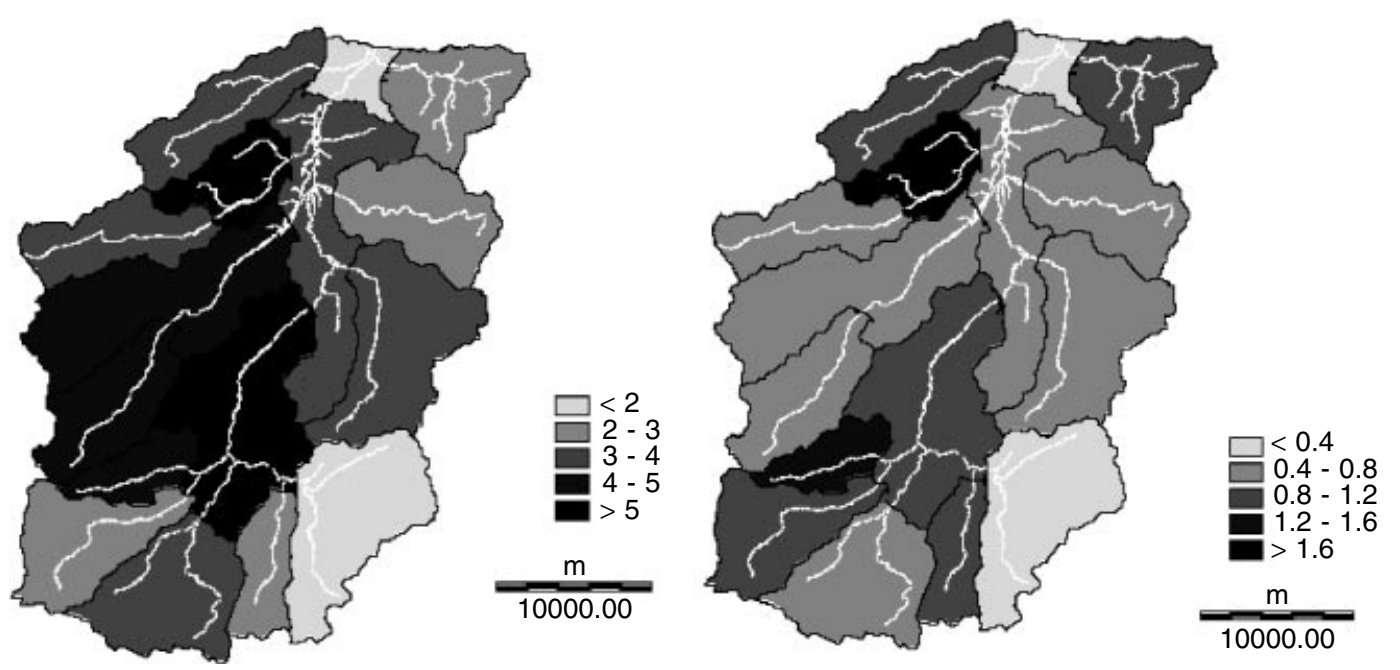

Figure 7. Left: predicted mean annual soil erosion $\left(\mathrm{tha}^{-1} \mathrm{a}^{-1}\right)$; Right: predicted mean annual area-specific sediment yield $\left(\mathrm{t} \mathrm{ha} \mathrm{a}^{-1} \mathrm{a}^{-1}\right)$ for subcatchments of the Dijle catchment. River channels are in white, borders of subcatchments in black

river system. These areas are not necessarily the same as those producing most erosion, as most of the eroded sediment is deposited within the catchment, before reaching the river system. The Dijle catchment was split up in seven subcatchments (Figure 7). For each subcatchment an average erosion rate was calculated by taking the average of all the pixels of the erosion map. An average sediment export value was calculated by summation of the sediment input in all the river grid cells in the subcatchment. This value was divided by the area of the subcatchment. Soil conservation measures in areas with a high sediment export value will have the most effect on the suspended load in the river system.

Since the model is spatially distributed it is possible to evaluate the impact of land use changes and land conservation techniques on sediment yield. This kind of analysis is not possible with spatially lumped models since they cannot take into account the spatial pattern of land use and topography and the correlation between both.

The model presented here uses a steepest descent algorithm to route the sediment over the landscape. This is only a rough approximation of the exact trajectory that the eroded sediment follows. In reality, small landscape elements like roads, hedges and field boundaries interfere with the topographic flowpaths. However, at the scale of a catchment it is not feasible to gather all this detailed information and implement it in the model structure. Another approximation is the use of only two transport capacity coefficients: one for arable land and one for non-eroding surfaces. The variability of the transport capacity between different crop types for example is not taken into account. For calibration of a larger set of transport capacity coefficients, however, a much larger dataset with observed sediment yield values would be necessary. Because of these simplifications the detailed spatial pattern of erosion and sediment deposition values within the catchment is probably much less reliable than the prediction of the total sediment delivery.

\section{CONCLUSIONS}

It can be concluded that a rather simple model with only elementary process descriptions can be used to predict the sediment delivery by surface runoff from hillslopes to rivers in small catchments with an acceptable accuracy. Model application is in principle not restricted by the size of the catchment on condition that digital elevation data and land use data are available. It should be kept in mind that model parameterization is scale-dependent. Therefore the parameters have to be recalibrated if the model is run at another grid-size.

In this study SEDEM was calibrated for typical rural catchments in Belgium. For application in other areas the RUSLE parameters and the transport capacity coefficients have to be recalibrated to get the appropriate 
values for the local soil and land use types. Therefore the acquisition of reliable long-term sediment yield data remains very important.

Sediment yield values predicted by the distributed model are significantly more accurate than the predictions using a lumped regression model. Apart from more accurate predictions, the distributed model provides information that cannot be obtained from a lumped regression model, like the identification of the land units delivering most of the sediment to the river system. The impact of different land use scenarios and soil conservation measures can also be assessed. Therefore the model could be a useful tool in integrated environmental watershed management.

\section{REFERENCES}

Atkinson E. 1995. Methods for assessing sediment delivery in river systems. Hydrological Sciences 40(2): $273-280$.

Bazoffi P, Baldasarre G, Vasca S. 1996. Validation of the PISA2 model for the automatic assessment of reservoir sediment deposition. In Proceedings of the International Conference on Reservoir Sediment Deposition, Albertson M (ed.). Colorado State University: 519-528.

Bollinne A. 1982. Etude et Prévison de l'érosion des sols limoneux cultivés en moyenne Belgique. PhD Thesis, Université de Liège.

Bollinne A, Laurant A, Boon W. 1979. L'érosivité des précipitations a Florennes - Révision de la carte des isohyètes et de la carte d'érosivité de la Belgique. Bulletin de la Société Géographique de Liège 15: 77-79.

Boyce RC. 1975. Sediment routing with sediment delivery ratios. In Present and Prospective Technology for Predicting Sediment Yields and Sources. US Department of Agriculture, Publication ARS-S-40: 61-65.

Brasington J, Richards K. 1998. Interactions between model predictions, parameters and DTM scales for topmodel. Computer and Geosciences 24(4): 299-314.

Clark Labs. 1999. Idrisi Guide to GIS and Image Processing. Clark University: Worcester, USA.

Declercq F, Poesen J. 1991. Erosiekarakteristieken van de bodem in Laag-en Midden-België. Tijdschrift van de Belg. Ver. Aardr. Studies BEVAS 1: $29-46$

Desmet PJJ, Govers G. 1995. GIS-based simulation of erosion and deposition patterns in an agricultural landscape: a comparison of model results with soil map information. Catena 25: 389-401.

Desmet PJJ, Govers G. 1996. A GIS procedure for automatically calculating the USLE LS-factor on topographically complex landscape units. Journal of Soil and Water Conservation 51: 427-433.

Desmet PJJ, Govers G. 1997. Two-dimensional modelling of the within-field variation in rill and gully geometry and location related to topography. Catena 29: 283-306.

Ferro V, Minacapilli M. 1995. Sediment delivery processes at basin scale. Hydrological Sciences Journal 40(6): $703-717$.

Ferro V, Porto P, Tusa G. 1998. Testing a distributed approach for modelling sediment delivery. Hydrological Sciences Journal 43(3): $425-442$.

Foster GR. 1982. Modelling the erosion process. In Hydrologic Modelling of Small Watersheds, Haan CT, Johnson HP, Brakensiek DL (eds). ASAE: St Joseph.

Gao J. 1998. Impact of sampling intervals on the reliability of topographic variables mapped from grid DEMs at a microscale. International Journal of Geographical Information Science 12(8): 875-890.

Gilles M, Lorent J. 1966. Debiet en lading van de Dijle. Acta geographica Lovaniensa 4: 48-56.

Govers G, Poesen J. 1988. Assessment of the interrill and rill contributions to total soil loss from an upland field plot. Geomorphology 1: $343-354$

Gulinck H, Janssens K, Sanders J. 1996. Digitale versie van de Bodemgebruikskaart Vlaanderen. OC-GIS Vlaanderen: Brussels.

Huybrechts W, Verbeelen D, Van der Beken A. 1989. Meting van het sedimenttransport in de Dijle te Korbeek-Dijle. Water 45: 55-59.

Klaghofer E, Summer W, Villeneuve JP. 1992. Some remarks on the determination of the sediment delivery ratio. IAHS Publication 209: $113-118$.

Li Z. 1991. Effects of check points on the reliability of DTM accuracy estimates obtained from experimental tests. Photogrammetric Engineering and Remote Sensing 57(10): 1333-1340.

McCool DK, Foster GR, Mutchler CK, Meyer LD. 1989. Revised slope length factor for the Universal Soil Loss Equation. Transactions of the American Society of Agricultural Engineers 32(5): 1571-1576.

Morgan RPC, Quinton JN, Smith RE, Govers G, Poesen JWA, Auerswald K, Chisci G, Torri D, Styczen ME. 1998. The European soil erosion model (EUROSEM): a dynamic approach for predicting sediment transport from fields and small catchments. Earth Surface Processes and Landforms 23: 527-544.

Nash JE, Sutcliffe JV. 1970. River flow forecasting through conceptual models. Part I. A discussion of principles. Journal of Hydrology 10: $282-290$.

Nearing MA, Foster GR, Lane LJ, Finkner SC. 1989. A process-based soil erosion model for USDA-Water Erosion Prediction Project Technology. Transactions American Society of Agricultural Engineers 32: 1587-1593.

Pilotti M, Bacchi B. 1997. Distributed evaluation of the contribution of soil erosion to the sediment yield from a watershed. Earth Surface Processes and Landforms 22: 1239-1251.

Renard KG, Foster GR, Weesies GA, McCool DK, Yoder DC. 1997. Predicting soil erosion by water: a guide to conservation planning with the Revised Universal Soil Loss Equation (RUSLE). USDA Agricultural Handbook 703.

Roehl JE. 1962. Sediment source areas, delivery ratios and influencing morphological factors. IAHS Publication 59: $202-213$.

Steegen A, Govers G, Nachtergaele J, Takken I, Beuselinck L, Poesen J. 2000. Sediment export by water from an agricultural catchment in the Loam Belt of central Belgium. Geomorphology 33: 25-36.

Steegen A, Govers G, Takken I, Nachtergaele J, Merckx R. (2001). Factors controlling sediment and phosphorus export from two Belgian catchments. Journal of Environmental Quality 30: 1249-1258. 
USDI. 1987. Design of Small Dams. A Water Resources Technical Publication. (third edition). United States Department of the Interior, Bureau of Reclamation: Denver, Colorado.

Vandaele K. 1997. Temporele en ruimtelijke dynamiek van bodemerosieprocessen in landelijke stroomgebieden (Midden-België). Een terreinstudie. PhD Thesis, KU Leuven, Belgium.

Vandaele K, Poesen J. 1995. Spatial and temporal patterns of soil erosion rates in an agricultural catchment, Central Belgium. Catena 25(1-4): 213-226.

Vanoni VA. 1975. Sediment Deposition Engineering. ASCE Manuals and Reports on Engineering Practices, No. 54.

Van Oost K, Govers G, Desmet. PJJ. 2000. Evaluating the effects of landscape structure on soil erosion by water and tillage. Landscape Ecology 15(6): 579-591.

Van Rompaey A, Govers G, Waumans T, Van Oost K, Poesen J, Desmet J. 2000. Een regionale bodemerosierisicokaart voor Vlaanderen. @WEL 3: 1-6.

Verheye W, Ameryckx J. 1988. Mineral fractions and classification of soil texture. Pédologie 38: 215-225.

Verstraeten G, Poesen J. 1999. The nature of small-scale flooding, muddy floods and retention pond sediment deposition in central Belgium. Geomorphology 29(3-4): 275-292.

Verstraeten G, Poesen J. 2000. Assessment of sediment-fixed nutrient export from small drainage basins in central Belgium using retention ponds. IAHS Publication 263: 243-249.

Verstraeten G, Poesen J. (2001). Factors controlling sediment yield from small intensively cultivated catchments in a temperate humid climate. Geomorphology 40: 123-144.

Walling DE. 1983. The sediment delivery problem. Journal of Hydrology 65: 209-237.

Wishmeier WH, Smith DD. 1978. Predicting rainfall erosion losses: a guide to conservation planning. USDA Agricultural Handbook 537.

Zevenbergen LW, Thorne CR. 1987. Quantitative analysis of land surface topography. Earth Surface Processes and Landforms 12: 47-56.

Zhang X, Drake NA, Wainwright J, Mulligan M. 1999. Comparison of slope estimates from low resolution DEMs: scaling issues and a fractal method for their solution. Earth Surface Processes and Landforms 24: 763-779. 